\title{
Pyrrolizidine Alkaloids: Chemistry, Pharmacology, Toxicology and Food Safety
}

\author{
Rute Moreira, David M. Pereira * (D), Patrícia Valentão ${ }^{(D)}$ and Paula B. Andrade * (D) \\ REQUIMTE/LAQV, Laboratório de Farmacognosia, Departamento de Química, Faculdade de Farmácia, \\ Universidade do Porto, R. Jorge Viterbo Ferreira, nº 228, 4050-313 Porto, Portugal; \\ rutemartinsmoreira@hotmail.com (R.M.); valentao@ff.up.pt (P.V.) \\ * Correspondence: dpereira@ff.up.pt (D.M.P.); pandrade@ff.up.pt (P.B.A.); \\ Tel.: +351-220-428-655 (D.M.P.); +351-220-428-654 (P.B.A.)
}

Received: 19 April 2018; Accepted: 23 May 2018; Published: 5 June 2018

\begin{abstract}
Pyrrolizidine alkaloids (PA) are widely distributed in plants throughout the world, frequently in species relevant for human consumption. Apart from the toxicity that these molecules can cause in humans and livestock, PA are also known for their wide range of pharmacological properties, which can be exploited in drug discovery programs. In this work we review the current body of knowledge regarding the chemistry, toxicology, pharmacology and food safety of PA.
\end{abstract}

Keywords: pyrrolizidine alkaloids; chemistry; toxicity; pharmacological properties; food safety

\section{Introduction}

Alkaloids are a diverse group of amino acid-derived and nitrogen-bearing molecules that display a wide range of roles in nature, where they occur in plants, microorganisms or animals [1]. In plants, alkaloids can be found in the form of salts of organic acids, mainly malate, acetate and citrate, or combined with other molecules, such as tannins [1]. Most alkaloids display basic properties and present a lipophilic character, being soluble in apolar organic solvents and alcohol [1].

Several alkaloids are known for their remarkable biological properties, which can be either marked toxicity or potent pharmacological capacity [2]. The class of alkaloids has a long history of use, both lawful and illicit, as pharmaceuticals, stimulants and narcotics [3].

Within the many known families of alkaloids, pyrrolizidine alkaloids (PA) have been receiving increasing attention due to their occurrence in several species relevant for human and animal nutrition, as well as for their toxicological and pharmacological properties. The increasing awareness of PA contamination in all sorts of foodstuff worldwide justifies the interest and concern around this topic. Although in most cases their levels are insufficient to cause acute poisoning, they are frequently consumed in quantities that exceed the maximum daily intake suggested by authorities, which can be a contributory factor to chronic diseases.

This work reviews the available information on PA, mainly regarding their chemistry, toxic and pharmacological properties, and food safety.

\section{The Chemistry of PA}

PA are a group of alkaloids derived from ornithine that are distributed in plants of certain taxa, being also found in insects that uptake them for defense against predators [1,4]. They rarely occur in the free form as a pyrrolizidine base, being instead found as esters (mono-, di- or macrocyclic diesters) formed by a necine base (amino alcohols) and one or more necic acids (mono- or dicarboxylic aliphatic acids), which are responsible for their structural diversity [1,5]. They are usually found in the form of tertiary bases or pyrrolizidine alkaloids $N$-oxides (PANO) (Figure 1) $[1,5,6]$. 


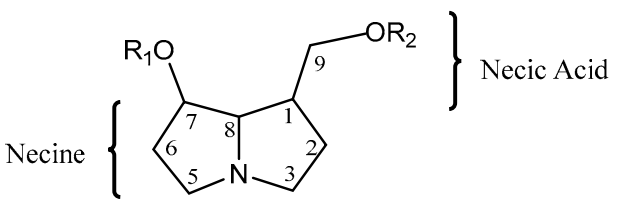

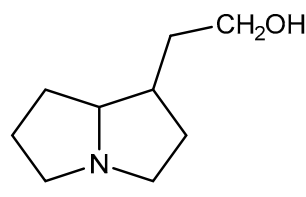

1,2-Dihydro

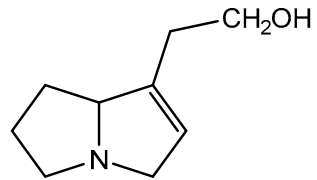

1,2-Unsaturated

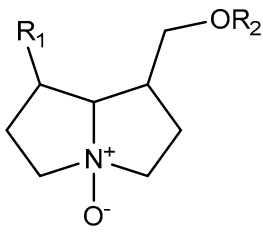

$N$-oxide

Figure 1. Structure of a PA and its different forms. $R_{1}$ and $R_{2}$ correspond to different necic acids.

Amino alcohols, or necines, are derived from pyrrolizidine. The pyrrolizidine core, comprising two saturated five-membered rings with a nitrogen atom between them, sometimes displays a double bond in the 1,2 position, which frequently results in enhanced toxicity [7]. They can also have a single alcohol at C-1, a second alcohol in position C-7 (di-hydroxylated) and less often a third in C-2 or C-6 (tri-hydroxylated) [8-10]. Esterification can take place at C-7 and/or C-9 positions [9].

According to the structure of the necine base, PA may be sorted into four groups: retronecine-, heliotridine-, otonecine- and platynecine-types (Figure 2) [11]. Retronecine-, otonecineand heliotridine-types are unsaturated bases, while platynecine-type is saturated [12,13]. From a structural point of view, otonecine is the most distinct among all types, since it is oxidized at C-8 and displays a monocyclic ring, thus diverging from the other groups, which display a bicyclic ring $[8,10,14]$. Retronecine and heliotridine are diastereomers, with distinct orientation at position C-7 [15].

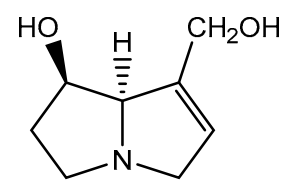

Retronecine

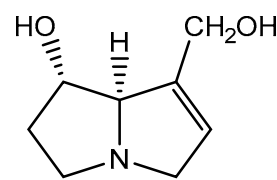

Heliotridine

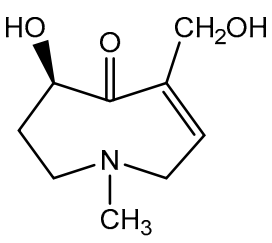

Otonecine

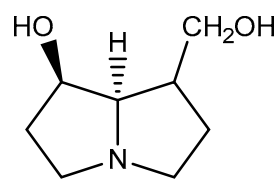

Platynecine

Figure 2. Groups of PA, according to the necine base.

Necic acids are aliphatic carboxylic acids that can be simple (angelic and tiglic acids), monocarboxylic acids with hydroxyisopropylbutanoic structures at C-7 (trachelantic and viridifloric acids) or dicarboxylic acids at C-8 or at C-10 (senecic and isatinecic acids) (Figure 3) [1].

The combination of the above-mentioned structures results in mono- or di-esters. Within the monocarboxylic acids, characteristic of the Boraginaceae family, some have a hydroxyl group at C-9 esterified by a hydroxyisopropylbutanoic acid, such as intermedine (Figure 4) [1]. In cases where there is a second necic acid, it usually occurs in the hydroxyl group of C-7, in the form of angelic acid or tiglic acid, as in echimidine (Figure 5) [1]. Macrocyclic diesters, characteristic from Asteraceae family, have also been described, which correspond to C-7 and C-9 esterified by a dicarboxylic acid (Figure 6) [1]. Unusually, necines may be esterified with aromatic or arylalkyl acids [1].

According to the most widely accepted pathway, the biosynthesis of the pyrrolizidine core begins with a $\mathrm{NAD}^{+}$-dependent condensation of two molecules of putrescine. It should be highlighted that this initial step is disputed by some authors, which advocate the involvement of one molecule of putrescine and one molecule of spermidine, the latter providing the aminobutyl group [16-18]. Interestingly, it could be the case that both theories are correct, as suggested by the finding that bacterial homospermidine synthase is able to accept either putrescine and spermidine as a substrate [19]. 
Regardless of the initial step, in both cases the reaction is catalyzed by homospermidine synthase and the result is the symmetrical intermediate homospermidine [1]. Subsequently, homospermidine is cyclized to the corresponding iminium ion, which is reduced and cyclized to trachelanthamidine and isoretronecanole (Figure 7A) [20].

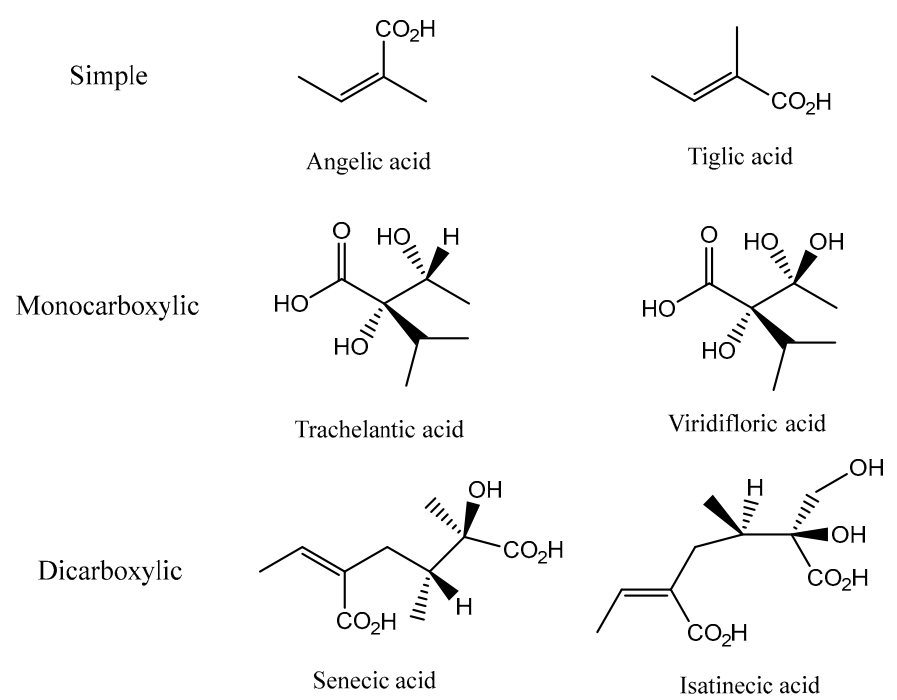

Figure 3. Chemical structures of necic acids.

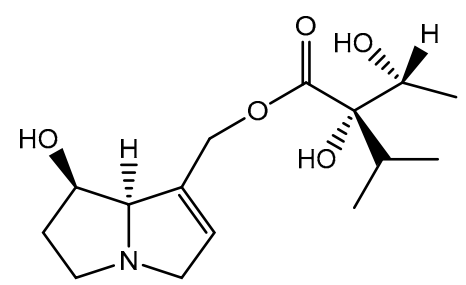

Figure 4. Chemical structure of intermedine, an ester of monocarboxylic acid.

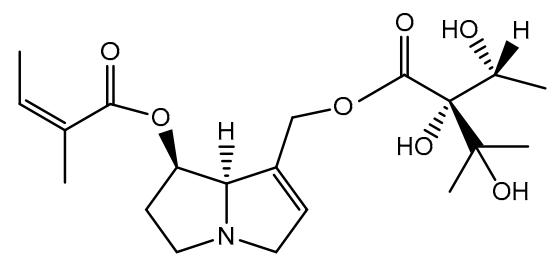

Figure 5. Chemical structure of echimidine, a diester of monocarboxylic acid.
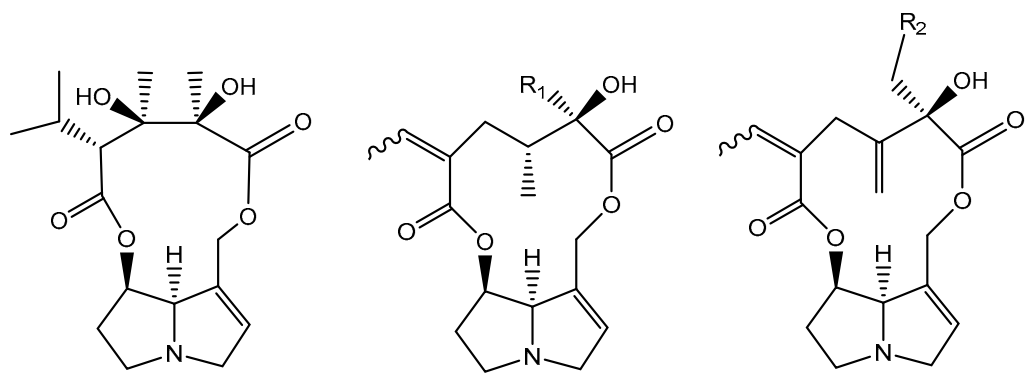

Figure 6. Chemical structure of tricodesmine, senecionine $\left(\mathrm{R}_{1}=\mathrm{H}\right) /$ retrorsine $\left(\mathrm{R}_{1}=\mathrm{OH}\right)$ and seneciphylline $\left(\mathrm{R}_{2}=\mathrm{H}\right) /$ riddeline $\left(\mathrm{R}_{2}=\mathrm{OH}\right)$, macrocylic diesters. 
Regarding necic acids, they are mostly derived from L-valine, L-leucine, L-isoleucine and L-threonine [20].

The formation of monocarboxylic acids with five carbon atoms, such as angelic, tiglic and sarracinic acid, takes place through the metabolization of threonine, which in turn proceeds from via $\alpha$-ketobutyric acid, also called 2-oxobutanoic acid. The interaction between this compound and pyruvate yields isoleucine [20].

With respect to senecioic, viridifloric and trachelanthic acids, the precursor involved is valine, which suffers a conversion into these necic acids, via an acyloin reaction with activated acetaldehyde [20].

In the case of dicarboxylic acids such as senecic acid, with ten carbon atoms (Figure 7B), cyclization of the open-chain monocarboxylic acid diesters takes place [20]. The biosynthesis occurs in the roots, where they are formed as PANO [21]. Afterwards, due to their high solubility in water, they are easily transported to the aerial parts so they can be stored in cell vacuoles [21].

Concerning the chemical synthesis, there has been an immense amount of research conducted on the partial and total synthesis of numerous naturally-occurring PA and related non-natural analogues [22,23].

A

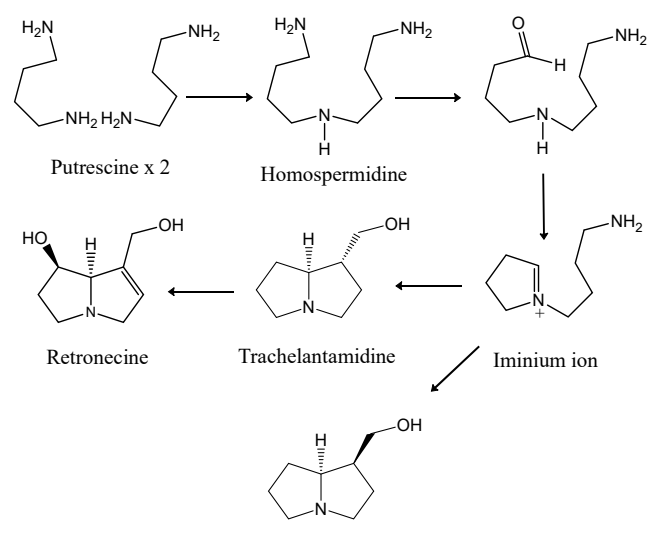

Isoretronecanole

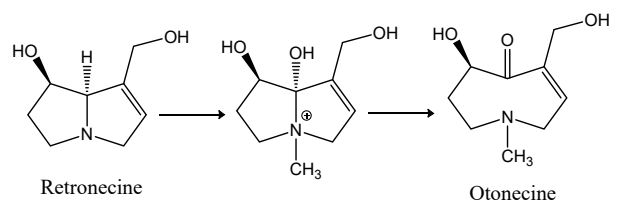

B
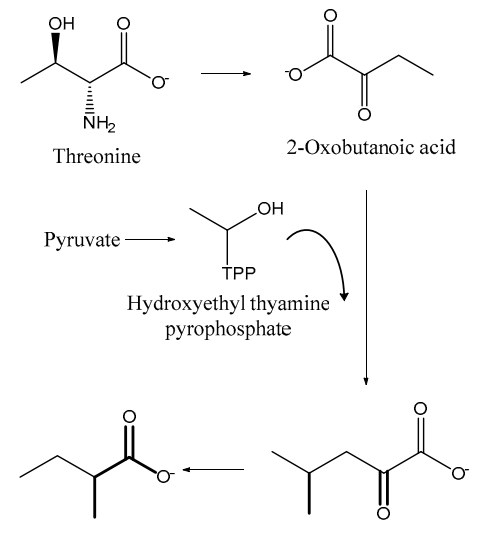

C5-unit of senecic acid

2-Oxoisocaproic acid

$\downarrow \uparrow$

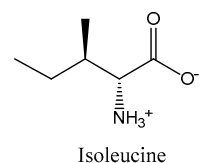

Figure 7. Biosynthesis of necines (A) and of senecic acid (B). Adapted from [1,16,20,24].

\section{Biological Activity of PA}

\subsection{Pharmacokinetics}

Concerning PA pharmacokinetics, after oral ingestion these compounds are absorbed from the gastrointestinal tract [25]. Most of them, around $80 \%$, are excreted in urine, feces and milk, a few being able to pass the placenta due to their high lipophilicity [25-27]. Bioactivation occurs mostly in the liver and, for this reason, this organ is the most affected by toxicity [28]. Other organs have been identified as targets, namely the lungs and kidneys [29]. The lung is the second most affected organ by the pyrroles formed after metabolic activation in the liver, since they can travel to the lungs through blood [29]. For PA to be excreted or exert toxicity, as with many xenobiotics, biotransformation must occur.

There are three principal pathways for the metabolic activation of PA, namely hydrolysis to produce necines and necic acids, $\mathrm{N}$-oxidation to form $\mathrm{PANO}$, and oxidation that leads to the formation 
of pyrrolic esters or dehydropyrrolizidine alkaloids (DHPA). Hydrolysis is an important detoxification route, promoting the clearance of these compounds [14], as well as $\mathrm{N}$-oxidation, which allows the formation of PANO that can be conjugated for excretion. However, PANO can reverse back into PA and suffer oxidation into DHPA [29]. This route is carried out mostly by cytochrome P-450 (CYP450) monooxygenases. In fact, the activity of these enzymes can partly explain the distinct susceptibility of different species to PA [29]. The isoforms of CYP450 involved in the metabolism leading to DHPA are generally CYP3A and CYP2B [30]. In the case of hydrolysis, liver microsomal carboxylesterases are involved [30]. However, only retronecine-type and heliotridine-type PA are capable of suffering $\mathrm{N}$-oxidation, otonecine-type PA being unable to generate PANO owing to their methylation in the nitrogen [14].

The balance between the formation of DHPA and the formation of detoxification compounds, such as necines, necic acids and PANO, is also important in explaining the distinct susceptibility of different species to these compounds [31].

The formation of DHPA happens through hydroxylation of the necine base at C-3 and C-8 positions, in the specific case of retronecine- and heliotridine-types [14]. In otonecine-type, an oxidative $\mathrm{N}$-demethylation is necessary [14]. After these highly reactive metabolites are formed, they can bind to glutathione (GSH) to form GSH conjugates and in doing so, they can be eliminated [32], which is the reason that conjugation to GSH is considered a detoxification route [32]. In the same way, pyrrolic esters can bind to proteins and deoxyribonucleic acid (DNA) and, consequently, they can form adducts. These metabolites can also suffer hydrolysis and be transformed in dehydronecines, which are also toxic metabolites, but are less reactive than the previously mentioned form [32]. Figure 8 illustrates the metabolism of PA.

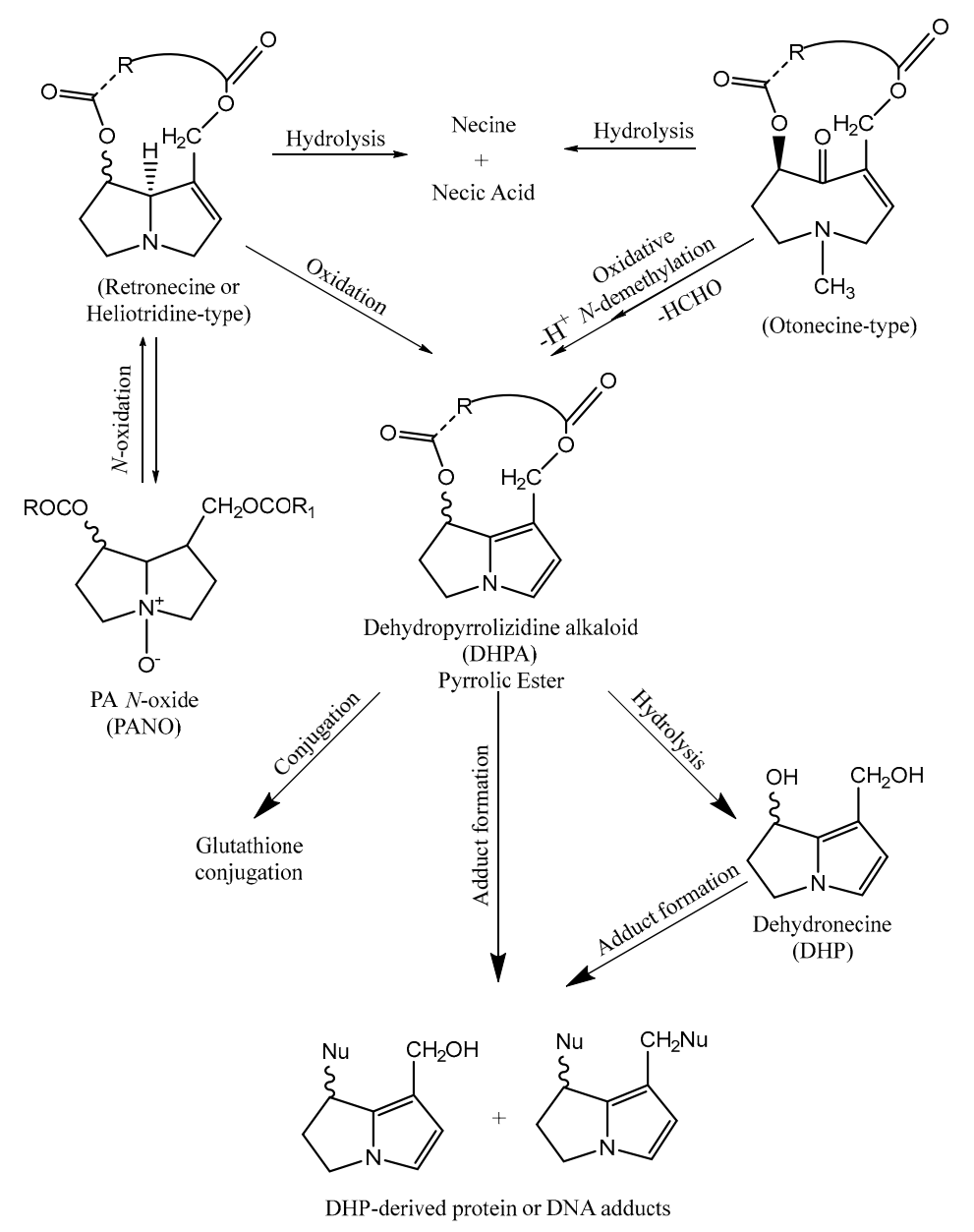

Figure 8. Metabolism of PA. 


\subsection{Pharmacological Properties}

Despite the toxicity described in some experimental models, which will be discussed later, PA exhibit an interesting spectrum of biological properties, which can be exploited in drug discovery programs.

\subsubsection{Anti-Microbial Activity}

Many alkaloids have been described as effective anti-microbials, which is in line with the defensive role of this class of secondary metabolites in plants [33].

In the specific case of PA, the anti-microbial activity of usaramine, monocrotaline and azido-retronecine against some bacteria has been demonstrated [34]. Usaramine was analyzed concerning its ability to inhibit biofilm formation in Staphylococcus epidermidis and Pseudomonas aeruginosa. Although the mechanism of action of usaramine remained unclear, it was possible to observe that it prevented the formation of biofilm by S. epidermis by about $50 \%$ at $1 \mathrm{mg} / \mathrm{mL}$. However, no effect was detected in the formation of biofilm by P. aeruginosa. Furthermore, monocrotaline and azido-retronecine demonstrated anti-Trichomonas vaginalis activity (concentrations up to $1 \mathrm{mg} / \mathrm{mL}$ ), being lethal to $70 \%$ and $85 \%$ of bacterial cells, respectively, while was devoid of toxicity towards T. vaginalis. Interestingly, no detectable damage in vaginal epithelial cells was found, a selectivity trait that may be relevant for the development of new drugs, such as topic anti-microbial agents.

In another study, the effects of PA from Senecio jacobaea L. were investigated for their effect on the growth of nine plant-associated fungi (five strains of Fusarium oxysporum, two of Fusarium sambucinum and two of Trichoderma sp.) [35]. A PA mixture consisting of senecionine (12\%), seneciphylline $(22 \%)$, jacobine $(24 \%)$ and jaconine $(24 \%)$ was highly effective, however high concentrations were required, the effective range of each individual PA varying from $0.33 \mathrm{mM}$ to 3.33 $\mathrm{mM}$, the most sensitive fungus belonging to the Trichoderma genus.

\subsubsection{Anti-Inflammatory Activity}

The inflammatory process is a physiological response of the body in order to eliminate, neutralize and/or destroy stimuli resulting from infection or tissue damage [36].

In inflammatory processes, the upregulation of inducible nitric oxide synthase as a consequence of pro-inflammatory mediators, such as cytokines, results in increased levels of nitric oxide (-NO), which plays an important role as a mediator in the inflammatory response [37]. Therefore, the regulation of its production in tissues may be important for the treatment of inflammation.

In a study by Huang et al., six new PA and two that were already known were isolated from Liparis nervosa (Thunb.) Lindl. and evaluated for their inhibitory capacity towards $\cdot \mathrm{NO}$ production by lipopolysaccharide (LPS)-challenged RAW 264.7 macrophages. The new molecules tested were nervosine I, nervosine II, nervosine III, nervosine IV, nervosine V, nervosine VI, and the previously-described PA were lindelofidine and labumine. Overall, all molecules were effective in this model, with $\mathrm{IC}_{50}$ values ranging from 2.16 to $38.25 \mu \mathrm{M}$ [38].

Another study with the same cell line led to the conclusion that PA present in an ethanol extract of the plant Heliotropium digynum (Forssk.) C. Chr inhibited the production of $\cdot \mathrm{NO}$ by $78 \%$ at $25 \mu \mathrm{g} / \mathrm{mL}$ [39]. In this work, the $\mathrm{IC}_{50}$ values found for heliotrine, heliotrine $\mathrm{N}$-oxide, 7-angelyolsincamidine $N$-oxide and europine were 52.4, 85.1, 105.1 and $7.9 \mu \mathrm{M}$, respectively.

Crotalaburnine was evaluated for its activity against increased vascular permeability and oedema induced by formaline, carrageenin, 5-hydroxytryptamine, dextran, bradykinin and prostaglandin [40]. This alkaloid was also tested against the formation of granulation tissues by cotton-pellet in rats. Its effects were compared with the activity of different compounds known for their anti-inflammatory properties, such as hydrocortisone [40]. Results showed that this PA was only efficient against acute 
edema induced by carrageenin and hyaluronidase, with a dose of $10 \mathrm{mg} / \mathrm{kg}$ [40]. In the cotton-pellet granuloma test it was shown that crotalaburnine was two times more potent than hydrocortisone [40].

\subsubsection{Anti-Cancer Activity}

In 1992, researchers in the area of pediatric cancer treated 31 children with acute lymphoblastic leukemia with indicine- $N$-oxide at two dose levels $\left(2000 \mathrm{mg} / \mathrm{m}^{2} /\right.$ day and $2500 \mathrm{mg} / \mathrm{m}^{2} /$ day) for 5 consecutive days [41]. Among the 12 patients treated with $2000 \mathrm{mg} / \mathrm{m}^{2} /$ day, 1 achieved a complete response after 6 months. On the other hand, of the 16 patients treated with $2500 \mathrm{mg} / \mathrm{m}^{2} /$ day, 1 reached a similar response after 1 month. The patient with chronic myelogenous leukemia displayed a partial response in 4 months. These results suggested that indicine- $N$-oxide is active in the treatment of acute lymphoblastic leukemia of children. However, it has a narrow therapeutic index and a very steep dose response curve. At the doses tested, mild acute hepatotoxicity was registered. However, the administration of doses $\geq 3000 \mathrm{mg} / \mathrm{m}^{2} /$ day for 5 days caused severe hepatotoxicity. Another study involving patients with ages between 4 and 67 years confirmed that indicine- $N$-oxide can induce remissions in cases of acute and chronic leukaemia at the concentration of $3000 \mathrm{mg} / \mathrm{m}^{2}$ administered daily for 5 days. In this study, only 1 out of 22 cycles of treatment resulted in liver failure [42].

In a study using different human cancer cell lines (cervical, breast, prostate and cervical squamous) indicine $\mathrm{N}$-oxide from Heliotropium indicum $\mathrm{L}$. inhibited the proliferation of the previous referred cancer cell lines, with $\mathrm{IC}_{50}$ values ranging from 46 to $100 \mu \mathrm{M}$ [43]. At these concentrations, cell cycle arrest at mitosis was detected, without noticeable changes in the organization of the spindle or interphase microtubules.

\subsubsection{Anti-HIV Activity}

Polyhydroxylated PA have been described as capable of interacting with human immunodeficiency virus (HIV) activity [44]. Australine and alexine, isolated from Castanospermum australe A. Cunn. \& C. Fraser ex Hook and Alexa Leiopetela Sandwith, are examples of these polyhydroxylated PA that in concentrations between 0.1 and $10 \mathrm{mM}$ inhibited, in distinct degrees, the activity of glycosidases, particularly the nitrogen-linked glycosylation process of HIV [44]. This event ultimately results in reduced cell fusion with the virions and, consequently, restricted syncytium formation [45].

A study from Taylor et al. with alexine and other four PA isolated from A. leiopetala and C. australe, respectively, also showed inhibitory activity against HIV-1 [46]. The positive results were obtained with 7,7a-diepialexine and an $\mathrm{IC}_{50}$ of $0.38 \mathrm{mM}$ was found. This anti-HIV activity was correlated with the inhibition of pig kidney $\alpha$-glucosidase 1 and the diminished cleavage of the precursor HIV-1 glycoprotein gp160.

\subsubsection{Acetylcholinesterase Inhibitors}

Acetylcholinesterase (AchE) is an enzyme that catalyzes the hydrolysis of acetylcholine (ACh) and other esters that act as neurotransmitters [47]. It plays an important role in neural function and it is mainly present in the synaptic gaps of central and peripheral nervous system, being responsible for terminate nerve impulses [47]. Overstimulation of ACh receptors can lead to disorders like depression. However, when present in low amounts, other diseases can manifest, namely Alzheimer and Myasthenia gravis $[47,48]$. For this reason, inhibitors of this enzyme are exploited as therapeutic targets [47].

Benamar et al. isolated four PA from Solenanthus lanatus DC., including a new one named 7-O-angeloylechinatine- $\mathrm{N}$-oxide, together with $3^{\prime}$-O-acetylheliosupine- $\mathrm{N}$-oxide, heliosupine- $\mathrm{N}$-oxide, and heliosupine [49]. All of these compounds inhibited AChE, with $\mathrm{IC}_{50}$ values between 0.53 and $0.60 \mathrm{mM}$. A more recent study, from the same author, with 7-O-angeloyllycopsamine- $\mathrm{N}$-oxide, echimidine- $\mathrm{N}$-oxide, echimidine, and 7-O-angeloylretronecine isolated from Echium confusum Coincy showed the inhibition of $\mathrm{AChE}$, with $\mathrm{IC}_{50}$ values ranging from 0.275 to $0.769 \mathrm{mM}$ [50]. 


\subsubsection{Miscellaneous}

A work with the leaves and inflorescences from Senecio brasiliensis (Spreng.) Less., performed by Toma et al. on mice and rats, shed a light on the possible use of PA in the treatment of ulcerogenic disease and stomach pain [51]. The therapeutic doses of PA were assessed by the administration of hydrochloric acid/ethanol to induce gastric ulcer. It was possible to perceive that the extent of the lesion induced was significantly reduced by $32.9 \%, 42.5 \%$ and $66.8 \%$ with concentrations of $12.5,25$ and 50 $\mathrm{mg} / \mathrm{kg}$ of PA extract (containing senecionine, integerrimine, retrorsine, usaramine and seneciphylline), respectively. In the same work, a dose of $12.5 \mathrm{mg} / \mathrm{kg}$ of the same PA extract was shown to ameliorate nonsteroidal anti-inflammatory drugs-induced gastric ulcer [51].

\section{Toxicity}

The toxicity of PA is largely documented [52,53], being almost exclusively associated to their metabolites.

In 1968, Mattocks introduced what is now considered the main mechanism responsible for the toxicity of PA, namely the binding of DHPA with groups containing sulphur, nitrogen and oxygen present in proteins, to form adducts, such as 2,3-dihydro-1H-pyrrolizineprotein [53], mainly in the site of formation [29]. Pyrroles can also penetrate the nucleus and react with DNA, ultimately causing DNA cross-links and DNA-protein cross-links with abnormal functions, which will be the cause of damage, mainly in the hepatocyte. They can pass to the adjacent Dissé space and into the sinusoidal lumen, where they attack sinusoidal cells [29]. The injury caused by the toxic metabolites in hepatocytes and in the walls of hepatic veins, for example, is what leads to veno-occlusive disease (VOD), called nowadays hepatic sinusoidal obstruction syndrome (HSOS) [29].

After that, several studies have been conducted to add to the knowledge of this toxicity mechanism. In a study by Lin et al., serum protein adducts were detected in a PA-induced HSOS patient for the first time [54]. The authors developed an analytical approach based on liquid chromatography-mass spectrometry (LC-MS) to study these adducts and have concluded that pyrrole-protein adducts could be potential biomarkers of PA-induced HSOS. In this specific study, the observed HSOS were confirmed to arise from the consumption of a PA-containing plant, Gynura segetum (L.) DC. Another study with PA-induced liver injury led to the conclusion that pyrrole-protein adducts were present in the blood of all the patients, further strengthening the case for their use as biomarkers for this kind of liver injury [55].

A study by Zhu et al. showed that these adducts can also be used as a biomarker of liver tumor formation [56]. As a result, they decided to carry a study to clarify the basic kinetics of PA-derived DNA adducts, namely their persistence in vivo. The conclusion was that they can be used to monitoring or predicting chronic liver diseases, since DHPA-derived DNA adducts have sufficient stability and persistence. In the single-dose exposure, the PA-derived DNA adducts exhibited dose-dependent linearity and persisted for up to 4 weeks. Following multiple dose treatment, they persisted more than 8 weeks. In addition, they exhibit correlation with the progression of liver damage caused. Another group achieved the same conclusion, with five hepatocarcinogenic PA (lasiocarpine, retrorsine, riddelliine, monocrotaline and heliotrine) and their corresponding PANO [57]. All of them being able to produce DNA adducts, through rat liver microsomal metabolism.

\subsection{Acute and Chronic Intoxications}

As previously mentioned, the liver is the main target of toxicity caused by PA, mainly because bioactivation occurs mostly in this organ. VOD is the clinical manifestation most frequently found, being considered a marker for PA intoxication [14]. The symptoms include vomiting, enlargement of the liver and bleeding diarrhea [14].

PA intoxication can be acute, sub-acute and chronic, each of them presenting different symptoms. Acute intoxication is characterized by hemorrhagic necrosis, hepatomegaly and ascites; in sub-acute 
there is a blockage of hepatic veins, which leads to HSOS (primary sinusoidal damage and parenchymal cell dysfunction [58]) [59]. Chronic PA exposure is characterized by necrosis, fibrosis, cirrhosis and proliferation of the bile duct epithelium [60,61]; liver failure and death is the highest level of this toxicity [59].

\subsection{Genotoxicity and Tumourigenicity}

In 1954, Schoental et al. discovered that retrorsine was capable of inducing tumors in experimental studies in animals [30,62]. Tumors developed in liver, lung, bladder, skin, brain, spinal cord, pancreas and gastrointestinal tract were found [25]. All PA known to have this effect belong to heliotridine-, retronecine- and otonecine-types.

The mechanism responsible for the formation of tumors was clarified by Yang et al., which established that riddelline (retronecine-type) form DNA adducts, in the form of DHPA [63]. In addition, it was also demonstrated by other authors that the levels of DNA adducts induced by DHPA were associated with the appearance of tumors, so they can be used as biomarkers of the tumourigenicity caused by PA [64]. Besides the formation of DNA adducts, these compounds can also react with proteins and trigger DNA cross-linking, sister chromatid exchange and chromosomal aberrations $[9,14,65]$.

Furthermore, PA were associated to skin cancer, since they can lead to photosensitization in animals upon their consumption and metabolism [66]. It is thought that phylloerythrin, a porphyrin derived from the damage of chlorophyll by microorganisms present in gastrointestinal tract, passes to the circulation and is excreted by the liver into the bile. However, a PA-damaged liver is unable to eliminate phylloerythrin, resulting in its accumulation in the blood and skin. In this case, when phylloerythrin is exposed to sunlight, the resulting metabolites can cause oxidative stress and lipid peroxidation in skin tissues and ultimately trigger the formation of tumors [66].

We were unable to find any reports of cancer cases in humans as a direct consequence of PA consumption. However, it has been shown before that the metabolism of riddelline in human liver microsomes is similar to that of rodents, including the formation of DNA adducts [67]. Since this PA induces liver tumors in rodents via formation of DNA adducts, it is plausible to conclude that this PA may also be genotoxic and tumorigenic to humans [67]. In fact, the National Toxicology Program in the United States has declared that riddelliine is "reasonably anticipated to be a human carcinogen" [68].

The potential role of PA in diseases such as cancer, pulmonary hypertension, congenital anomalies and liver diseases has been reviewed before [69]. These alkaloids are genotoxic and can slowly initiate diseases of this sort, which is problematic because clinicians are unware of PA dietary exposure. The authors defined six indicators that can suggest a dietary dehydroPA etiology, appointing, for example: "cirrhosis, especially if associated with HSOS and/or accumulation of copper in the liver" and "cancers and/or congenital anomalies where there is evidence of overt or asymptomatic HSOS, pulmonary arterial hypertension (PAH), bone deformities, or immunological deficiencies". If several of these indicators are present, the authors affirm that it is possible that a dietary exposure to PA is involved in the disease etiology.

\subsection{Other Types of Toxicity}

Lungs can also be a target of injury, since DHPA can travel from the liver into pulmonary arterioles, producing damage similar to the VOD [70]. After reaching this organ, thrombi in vessels and thickening in their walls leads to occlusion and inflammation [29]. Overall, the combination of these phenomena ultimately trigger pulmonary hypertension and subsequent congestive heart failure [29]. In a study by Culvenor et al. carried out on hooded Wistar rats, it was demonstrated that PA can elicit lung lesions, as result from low-level ( $0.025 \mathrm{mmoles} / \mathrm{kg}$ body weight) and long-term exposure to PA [71]. Two types of lung lesions were observed: intravascular accumulation of mononuclear cells ultimately resulting in venous occlusion, and extravascular alteration, in which the alveolar septa were thickened, 
and the number of cells increased. The authors also concluded that rats developing lung lesions always presented chronic liver lesions.

Neurotoxicity was also reported as a part of the poisoning by these substances, particularly by tricodesmine, including symptoms like encephalitis, characterized by vertigo and headaches, which could progress to delirium and loss of consciousness [70]. At the central nervous system, necrotic lesions have been described [72].

There are also reports of teratogenicity in the literature, justified by the fact that some PA can pass the placenta, as referred above. For example, a case of hepatic VOD in a newborn of a woman who consumed herbal tea prepared from Tussilago farfara L. was described [73]. Also, in Australia, the consumption of Senecio madagascariensis Poir. by a mare was reported to lead to hepatic failure in a foal of two months [74].

A study with clivorine isolated from Ligularia hodgsonii Hook, in concentrations between 10 and $100 \mu \mathrm{M}$, showed that this PA can induce DNA fragmentation, compatible with apoptosis, in human foetal hepatocyte line and mouse hepatocytes, with $\mathrm{IC}_{50}$ of $40.8 \mu \mathrm{M}[75,76]$.

\subsection{Chemical and Biological Aspects That Influence the Toxicological Profile}

The structural basis for the toxicological effects of PA have been described in some works. The presence of the 1,2 double bond, as found in retronecine-, heliotridine- and otonecine-types, has been associated with the toxic effects of PA [52], as well as the presence of one or two hydroxyl groups attached to the pyrrole ring [29]. Several studies also suggest that the presence of a methyl group at C-1 is relevant, as is the presence of two esterified groups and branching in at least one of the carboxylic acids [29]. For this reason, PA that exert the highest toxicity are cyclic diesters, monoesters being the ones that cause the lowest level of injuriousness; between them are the open-chain diesters, which cause an intermediary toxicity [25]. The existence of relationship between the esterification level and the toxicity has been suggested, as, for example, macrocyclic DHPA were revealed to be more toxic than open chain diesters [28].

Toxicity of PA can be influenced by age and gender, since members of masculine sex are a group of risk, as well as children and fetuses, which are the most vulnerable group [59]. There are also toxicological differences between distinct PA within a species and of the same PA in different species [77].

PA poisoning is exacerbated with bacteria and metals. A study from Yee et al. showed that the simultaneous exposure to low doses of monocrotaline, which would not normally cause damage, and LPS elicited hepatotoxicity [78]. In this case, centrilobular and midzonal liver lesions were registered. Aston et al. studied the impact of a copper-rich diet in PA toxicity [79]. The results showed that retrorsine and copper together led to a more serious liver damage than retrorsine alone, a result that was confirmed in another work [80].

\section{Human and Animal Consumption of PA}

\subsection{Legal Framework}

With the increasing consumption of herbal medicines, PA poisoning has begun to be regarded as a public health problem. Consequently, some countries established regulations about PA in foodstuff. In the United States of America, the Food and Drug Administration ordered the ban of all PA-containing comfrey preparations from the market [81]. The German Federal Department of Health restricted the use of these preparations to 6 weeks and in a level of less than $1 \mu \mathrm{g} /$ day; if the use was prolonged in time, the daily limit should be reduced to $0.1 \mu \mathrm{g}$ [82]. Another regulation implemented was the labeling of these products with the following statement: "Not to be used in pregnancy and during the lactation period.", due to the susceptibility of fetuses and children to diseases instigated by PA $[82,83]$. In the European Union, the European Food Safety Authority (EFSA) determined that the ingestion of toxic PA induces VOD and that they have carcinogenic effects in rodents [84]. In 2011, EFSA concluded 
that no tolerable daily intake could be established. They followed the margin of exposure (MOE) approach, a "ratio of two factors, which assesses for a given population the dose at which a small but measurable adverse effect is first observed and the level of exposure to the substance considered". The MOE defined was of 1:10,000 for an exposure of $7 \mathrm{ng} / \mathrm{kg}$ of body weight per day. As an example, for a $70 \mathrm{~kg}$ individual, this corresponds to a daily exposure of approximately $500 \mathrm{ng}$ of PA [85]. The European Medicines Agency, based on toxicological considerations and the available guidelines for assessment/management of genotoxic carcinogens, also showed concern about the hazards of PA, recommending a maximum daily intake of $0.35 \mu \mathrm{g}$ PA/day for a person with a body weight of $50 \mathrm{~kg}$ and life-long exposure [86]. Austria excluded all products with PA from the market, and in the Netherlands, all foodstuff, herbal preparations, and extracts of plants known to have PA were limited to $1 \mu \mathrm{g} / \mathrm{kg}$ or $1 \mu \mathrm{g} / \mathrm{L}$ in the ending product [87].

Risk assessments of PA are based on animal studies and, for this reason, different approaches were suggested to translate animal doses to human exposure risks. Guidance documents have been developed taking into account differences between species that can influence the toxicity, namely the metabolic pathways $[88,89]$. Some groups reviewed the relevance of animal models to predict the effects of PA in humans [90]. The findings highlight that direct comparison between animal and human results is not always possible. For example, the PA-induced tumourigenicity previously reported for animals has not, to this day, been demonstrated in humans. Anyway, it is still an open question whether the differences between species should exclude the results in animals for quantitative risk assessment in humans [91].

As extracted from the conclusions drawn by the several risk assessment authorities, there is no consensus in the PA daily intake limit, although they all concur that PA are a class of undesirable compounds in food. For this reason, quality control of foodstuffs is pivotal and can be important for establishing legally binding limits. The first step should be the choice of an appropriate and universal analytical method for PA, as it was requested by EMA to the European Pharmacopeia [91]. As far as we could determine, this is being undertaken at the moment [92].

\subsection{Data from Literature}

Due to the presence of PA in several species relevant for human and animal nutrition, they may pose a threat to human health through their presence in herbal teas, herbal medicines, dietary supplements, vegetables, cereals, wheat grain, honey and pollen [93-98]. Cases of intoxication by contaminated cereals, teas, and salads have been extensively reported $[97,99,100]$.

In 1903, it was recognized by Gilruth that tansy ragwort (S. jacobaea) produced chronic liver disease in cattle [101,102]. Afterwards, in 1956, a study by Bull and Dick showed that species from Crotalaria spp. led to comparable diseases [103]. A serious outbreak with the consumption of bread made from wheat contaminated with seeds of Heliotropium sp. plants, which contain PA, happened in Afghanistan, in 1974-1975 [104]. The patients exhibited ascites and emaciation, typical of hepatic VOD. Equally, in Tajikistan (1993), an epidemic was observed involving wheat contaminated by Heliotropium lasiocarpum Fisch. \& C.A.Mey. As consequence, 3906 cases of liver diseases were registered, leading to over 60 deaths [105].

In 1989, the International Program on Chemical Safety, an agency of the World Health Organization and Food and Agriculture Organization, published the "Pyrrolizidine Alkaloids Health and Safety Guide" [83]. This guide contained statements about the hazards for humans and animals and the confirmation that contaminated grain, herbal medicines, beverages, foodstuff or grazing with PA could cause acute or chronic illness [83].

PA poisoning was initially a problem, mainly in developing countries, as result of the use of traditional medicines containing PA (Table 1) [100]. However, in the last years, there has been a growing focus on this type of medicine in industrialized countries, thus making this problem a wider concern [100]. In Europe, chronic toxicity due to long-term consumption of food or herbal medicines containing these alkaloids is now a reality [106]. 
Table 1. Medicinal species containing PA $[17,20]$.

\begin{tabular}{|c|c|c|}
\hline Family & Plant & Reference \\
\hline Apiaceae & Foeniculum vulgare Mill.; Pimpinella anisum L.; Carum carvi L. & [107] \\
\hline Apocynaceae & $\begin{array}{l}\text { Amphineurion marginatum (Roxb.) D. J. Middleton; Alafia cf. } \\
\text { caudata Stapf }\end{array}$ & [108] \\
\hline Asteraceae & $\begin{array}{l}\text { Eupatorium cannabinum L.; Adenostyles alliariae (Gouan) Kern; } \\
\text { Emilia sonchifolia (L.) DC.; Petasites hybridus (L.) PH Gaertn., B. } \\
\text { Mey \& Scherb.; Petasites spurius (Retz) RCHB; S. jacobaea; } \\
\text { Senecio vulgaris L.; T. farfara; Senecio nemorensis L.; Ageratum } \\
\text { conyzoides L.; Chromolaena odorata (L.) R. M. King \& H. Rob.; } \\
\text { Eupatorium chinense L.; Eupatorium fortunei Turcz.; Eupatorium } \\
\text { japonicum Thunberg ex Murray.; Cacalia hastata L.; Cacalia } \\
\text { hupehensis Hand.-Mazz.; Crassocephalum crepidioides (Benth.) S. } \\
\text { Moore; Farfugium japonicum (L.) Kitam.; Gynura bicolor (Roxb. } \\
\text { ex Willd.) DC.; Gynura divaricata (L.) DC.; G. segetum; Ligularia } \\
\text { dentata (A.Gray) Hara; Petasites japonicus (Siebold \& Zucc.) } \\
\text { Maxim.; Senecio argunensis Turcz.; Senecio integrifolius (L.) } \\
\text { Clairv.; Senecio scandens Buch.-Ham. Ex D. Don; Syneilesis } \\
\text { aconitifolia (Bunge) Maxim.; Matricaria chamomilla L.; Gynura } \\
\text { pseudochina (L.) DC.; Gynura japonica (Thunb.) Juel; Packera } \\
\text { candidissima (Greene) W. A. Weber \& Á. Löve; Solanecio mannii } \\
\text { (Hook.f.) C. Jeffrey; Solanecio tuberosus (Sch. Bip. ex A. Rich.) C. } \\
\text { Jeffrey var. tuberosus; Bidens pilosa L.; Senecio longilobus Benth. }\end{array}$ & {$[60,107,109-118]$} \\
\hline Boraginaceae & $\begin{array}{l}\text { Alkanna tinctoria (L.) Tausch; Anchusa officinalis L.; Borago } \\
\text { officinalis L.; Cynoglossum officinale L.; Heliotropium arborescens } \\
\text { L.; Lithospermum officinale L.; Myosotis scorpioides L.; Symphytum } \\
\text { asperum Lepech; Symphytum caucasicum Bieb.; Symphytum } \\
\text { officinale L.; Symphytum tuberosum L.; Symphytum × uplandicum } \\
\text { Nyman; Arnebia euchroma (Royle) I. M. Johnst.; Cordia myxa L.; } \\
\text { Cynoglossum amabile Stapf \& J. R. Drumm; Cynoglossum } \\
\text { lanceolatum Forssk.; Cynoglossum zeylanicum (Vahl) Brand; } \\
\text { Cynoglossum grande Dougl. ex Lehm.; Cynoglossum virginianum } \\
\text { L.; Arnebia benthamii (Wall. ex G.Don.) Johnst.; H. indicum; } \\
\text { Lappula intermedia (Ledeb.) Popov; Lithospermum erythrorhizon } \\
\text { Siebold \& Zucc. }\end{array}$ & [119-123] \\
\hline Fabaceae & $\begin{array}{c}\text { Crotalaria albida Roth; Crotalaria assamica Benth.; Crotalaria } \\
\text { pallida Aiton; Crotalaria sessiliflora L.; Crotalaria } \\
\text { tetragona Andrews }\end{array}$ & / \\
\hline Lamiaceae & Melissa officinalis L. & [107] \\
\hline Orchidaceae & L. nervosa & / \\
\hline Urticaceae & Urtica dioica $\mathrm{L}$. & [107] \\
\hline
\end{tabular}

Several studies on food chemistry and food safety have shown that many of the foodstuff currently consumed are sources of this type of alkaloids. A recent study from Mulder et al. showed that the contamination of eggs and meat products with PA seems to be rare in the European Union [124]. Nevertheless, PA are sometimes found in milk, albeit in very low concentrations, since milk suffers from extensive processing, during which these compounds are diluted [124]. The class of PA found in milk revealed that Senecio spp. and species from the Boraginaceae family could be the origin of their occurrence [124].

In the last few years it has been reported that even herbal teas and teas not prepared from plants known to have PA in their composition, such as M. chamomilla and Mentha $\times$ piperita L., can have high amounts of these compounds, as consequence of cross-contamination [107,125]. When studying the distribution of PA in herbal teas, namely green, black, peppermint, rooibos, chamomile and one mix of herbs, it was observed that the most frequent was the senecionine-type (senecionine-, retrorsine-, seneciphylline-, senecivernine- $N$-oxides and their respective free bases) [124]. Lycopsamineand heliotrine-types were less frequently found, intermedine being the most common, followed by lycopsamine- $N$-oxide and heliotrine- $N$-oxide [124]. The highest average concentration was 
from senecionine- $N$-oxide (1.73 $\mu \mathrm{g} / \mathrm{L}$ and $64 \%$ frequency), followed by retrorsine-, seneciphylline-, senecivernine- $\mathrm{N}$-oxides and the corresponding free bases [124]. Together, these PA accounted for $76 \%$ of total PA content found in herbal teas; lycopsamine- and heliotrine-types accounted for $24 \%$, while monocrotaline-type was not present [124]. Moreover, PANO were found in higher concentrations than the corresponding free bases. High amounts of PA were also revealed in tea, namely in black and green tea from retail market, an unexpected finding [124]. As described before, different chemical types were identified, open-chain diesters being mainly perceived in fennel (F. vulgare) infusion and cyclic PA in black tea [107].

Concerning food supplements, the samples analyzed were often contaminated with PA, being the amounts highly variable [124]. The analysis was made considering three types of food supplements: supplements based on plants not known to produce PA (Valeriana officinalis L., Hypericum perforatum L.), supplements based on plants known to produce PA (B. officinalis, Eupatorium perfoliatum L., Eupatorium odoratum L., L. officinale, Pulmonaria officinalis L., S. officinale, Petasitis sp., P. hybridus, T. farfara), supplements containing bee products (pollen, propolis and royal jelly). Food supplements made from plant material known for their content in PA revealed the highest PA levels, those from lycopsamine-type (lycopsamine, intermedine, echimidine) being the more common [124]. However, the supplements made from plants not known to produce PA similarly demonstrated to have these compounds, probably due to cross-contamination. Supplements made of oil-based extracts of PA-producing plants were devoid of PA, whereas the presence of PA in supplements containing bee products was also confirmed [124].

Several studies have shown that the distribution of PA subclasses varies with the vegetal material [126]. For example, while pollen is richer in seneciphylline-type, in flower heads retrorsineand usaramine-types are more common [126].

Among the several food products that can harbor these toxins, honey is one of the most studied and important [126-128]. PA have been found in honey from various botanical and geographical origins [129]. Senecionine, echimidine and lycopsamine, in particular, were present in Echium spp. honey samples coming from Spain [130]. Considering the concentrations found by Kempf et al. in honey samples $(0.019-0.120 \mu \mathrm{g} / \mathrm{g})$ and that a common dose is 1 or 2 table spoons per day $(10-20 \mathrm{~g})$, it is possible to conclude that a honey consumer can easily exceed the recommended limit: maximum of $1.0 \mu \mathrm{g}$ of PA per day [129,131-135]. A study from Lucchetti et al. [127] revealed the presence of PA in nectar from Echium vulgare L. Echimidine corresponded to half of the PA content found and acetylechimidine, vulgarine, echiuvulgarine and acetylvulgarine were the other half. They also concluded that pollen frequently exhibited higher levels of PA than nectar, but the proportion of the diverse types of these compounds found in honey was more closely related to that found in nectar compared to that present in pollen. For this reason, there are some doubts about the origin of these toxins in honey, since it is composed by nectar, but also contains traces of pollen.

PA-containing plants known to be used in the production of honey can be found in Table 2.

Studies with pollen from $S$. vernalis revealed that PA-free honey can be contaminated when this pollen is added to it, probably by diffusion from pollen to honey [93]. For some authors, it was also clear that pollen contained much higher levels of PA than honey and that pollen appeared in it at low doses [126]. However, a study showed the opposite, specifically that a relationship between the concentration of pollen in the honey and its PA levels is not always found, since honeys with considerable amounts of PA on their composition are revealed to have low levels of pollen [129]. 
Table 2. Plants containing PA used in the production of honey in several countries.

\begin{tabular}{|c|c|c|}
\hline Country & Plant & Reference \\
\hline Argentine & Senecio grisebachii Baker & [136] \\
\hline Australia & $\begin{array}{l}\text { Echium plantagineum L.; E. vulgare; Eucryphia lucida (Labill) Baill; } \\
\text { Heliotropium amplexicaule Vahl; Heliotropium europaeum L. }\end{array}$ & [131] \\
\hline Brazil & C. pallida; Eupatorium sp. & {$[137,138]$} \\
\hline Bulgaria & T. farfara & [139] \\
\hline China & E. plantagineum; E. vulgare; Senecio spp.; C. officinale; Tussilago spp. & [140] \\
\hline Ethiopia & Solanecio angulatus (Vahl) C. Jeffrey & [109] \\
\hline Germany & E. vulgare; Phalaenopsis sp.; S. jacobaea; Senecio vernalis Waldst. \& Kit. & [126] \\
\hline Ghana & C. odorata; Eupatorium spp.; Ageratum spp. & [141] \\
\hline India & Crotalaria juncea L. & {$[76,142]$} \\
\hline Italy & $\begin{array}{c}\text { Echium sp.; Senecio erucifolius L.; Senecio inaequidens DC; S. jacobaea; S. } \\
\text { vulgaris; Robinia pseudoacacia L. }\end{array}$ & [143-145] \\
\hline New Zealand & E. vulgare; B. officinalis; Echium spp. & {$[134,140]$} \\
\hline Portugal & Echium sp. & [143] \\
\hline South Africa & S. inaequidens; Senecio pterophorus DC & {$[143,145]$} \\
\hline Spain & E. plantagineum; E. vulgare & [135] \\
\hline Switzerland & E.vulgare; Eupatorium sp.; Senecio sp. & {$[140,146]$} \\
\hline Thailand & E. odoratum & [147] \\
\hline Turkey & Myosotis sp. & [148] \\
\hline United Kingdom & Borago sp.; S. jacobaea & {$[140,149]$} \\
\hline United States & C. officinale; E. vulgare; S. jacobaea; S. vulgaris; S. officinale & {$[150,151]$} \\
\hline Uruguay & E. plantagineum & [152] \\
\hline
\end{tabular}

\section{Conclusions}

PA are a widespread group of secondary metabolites that can, in certain situations, pose a life threat to humans and animals, once they are present in a variety of foodstuff. These compounds have became known for their toxicity, as per several outbreaks that were registered, mainly in developing countries. However, in the last years, industrialized countries began to face this reality, when the use of traditional medicines increased. Despite this, some PA can also be useful, since they demonstrate pharmacological properties which can be further exploited by relying in medicinal chemistry strategies that can maintain bioactivity while reducing toxicity.

Thereby, for the sake of human and animal health protection, it is of great importance to further develop the information regarding the chemistry, pharmacology and toxicology of PA.

Acknowledgments: This work received financial support from National Funds (FCT/MEC, Fundação para a Ciência e Tecnologia/Ministério da Educação e Ciência) through project UID/QUI/50006/2013, co-financed by European Union (FEDER under the Partnership Agreement PT2020), from Norte Portugal Regional Operational Programme (NORTE 2020), under the PORTUGAL 2020 Partnership Agreement, through the European Regional Development Fund (ERDF) (project NORTE-01-0145-FEDER-000024).

Conflicts of Interest: The authors declare no conflict of interest.

\section{Abbreviations}

$\begin{array}{ll}\text { AChE } & \text { Acetylcholinesterase } \\ \text { ACh } & \text { Acetylcholine } \\ \text { CYP 450 } & \text { Cytochrome P450 } \\ \text { DHPA } & \text { Dehydropyrrolizidine alkaloid(s) } \\ \text { DNA } & \text { Deoxyribonucleic acid } \\ \text { EFSA } & \text { European Food Safety Authority }\end{array}$




$\begin{array}{ll}\text { GSH } & \text { Glutathione } \\ \text { HSOS } & \text { Hepatic sinusoidal obstruction syndrome } \\ \text { HIV } & \text { Human immunodeficiency virus } \\ \text { LPS } & \text { Lipopolysaccharide } \\ \text { MOE } & \text { Margin of exposure } \\ \cdot \text { NO } & \text { Radical nitric oxide } \\ \text { PA } & \text { Pyrrolizidine alkaloid(s) } \\ \text { PANO } & \text { Pyrrolizidine alkaloids } N \text {-oxide(s) } \\ \text { VOD } & \text { Veno-occlusive disease }\end{array}$

\section{References}

1. Bruneton, J. Farmacognosia, 2nd ed.; Acribia: Zaragoza Spain, 2008; ISBN 978-1-84585-006-7.

2. Rujjanawate, C.; Kanjanapothi, D.; Panthong, A. Pharmacological effect and toxicity of alkaloids from gelsemium elegans benth. J. Ethnopharmacol. 2003, 89, 91-95. [CrossRef]

3. Croteau, R.; Kutchan, T.M.; Lewis, N.G. Natural Products (Secondary Metabolites); John Wiley \& Sons: New York, NY, USA, 2000; Volume 24, pp. 1250-1319. ISBN 9780470714218.

4. Hartmann, T. Chemical ecology of pyrrolizidine alkaloids. Planta 1999, 207, 483-495. [CrossRef]

5. Cunha, A.P.D. Farmacognosia e Fitoquímica, 3rd ed.; Fundação Calouste Gulbenkian: Lisboa, Portugal, 2010; ISBN 9789723111422.

6. Valese, A.C.; Molognoni, L.; de Sá Ploêncio, L.A.; de Lima, F.G.; Gonzaga, L.V.; Górniak, S.L.; Daguer, H.; Barreto, F.; Oliveira Costa, A.C. A fast and simple LC-ESI-MS/MS method for detecting pyrrolizidine alkaloids in honey with full validation and measurement uncertainty. Food Control 2016, 67, 183-191. [CrossRef]

7. Hartmann, T.; Witte, L. Chemistry, biology and chemoecology of the pyrrolizidine alkaloids. Alkaloids Chem. Biol. Perspect. 1995, 9, 155-233.

8. De Fresno, Á.M.V. Farmacognosia General; Editorial Síntesis: Madrid, Spain, 1999; ISBN 8477386404.

9. Xia, Q.; Yan, J.; Chou, M.W.; Fu, P.P. Formation of DHP-derived DNA adducts from metabolic activation of the prototype heliotridine-type pyrrolizidine alkaloid, heliotrine. Toxicol. Lett. 2008, 178, 77-82. [CrossRef] [PubMed]

10. Rowell-Rahier, M.; Witte, L.; Ehmke, A.; Hartmann, T.; Pasteels, J.M. Sequestration of plant pyrrolizidine alkaloids by chrysomelid beetles and selective transfer into the defensive secretions. Chemoecology 1991, 2, 41-48. [CrossRef]

11. Gottschalk, C.; Ronczka, S.; Preiß-Weigert, A.; Ostertag, J.; Klaffke, H.; Schafft, H.; Lahrssen-Wiederholt, M. Pyrrolizidine alkaloids in natural and experimental grass silages and implications for feed safety. Anim. Feed Sci. Technol. 2015, 207, 253-261. [CrossRef]

12. Wang, Y.-P.; Fu, P.P.; Chou, M.W. Metabolic activation of the tumorigenic pyrrolizidine alkaloid, retrorsine, leading to DNA adduct formation in vivo. Int. J. Environ. Res. Public health 2005, 2, 74-79. [CrossRef] [PubMed]

13. Zhou, Y.; Li, N.; Choi, F.F.K.; Qiao, C.F.; Song, J.Z.; Li, S.L.; Liu, X.; Cai, Z.W.; Fu, P.P.; Lin, G.; et al. A new approach for simultaneous screening and quantification of toxic pyrrolizidine alkaloids in some potential pyrrolizidine alkaloid-containing plants by using ultra performance liquid chromatography-tandem quadrupole mass spectrometry. Anal. Chim. Acta 2010, 681, 33-40. [CrossRef] [PubMed]

14. Chen, T.; Mei, N.; Fu, P.P. Genotoxicity of pyrrolizidine alkaloids. J. Appl. Toxicol. 2010, 30, $183-196$. [CrossRef] [PubMed]

15. These, A.; Bodi, D.; Ronczka, S.; Lahrssen-Wiederholt, M.; Preiss-Weigert, A. Structural screening by multiple reaction monitoring as a new approach for tandem mass spectrometry: Presented for the determination of pyrrolizidine alkaloids in plants. Anal. Bioanal. Chem. 2013, 405, 9375-9383. [CrossRef] [PubMed]

16. Croteau, R.; Davis, E.; Hartmann, T.; Hemscheidt, T.; Sanz-Cervera, J.; Shen, B.; Stocking, E.; Williams, R. Biosynthesis: Aromatic Polyketides, Isoprenoids, Alkaloids; Springer: Berlin, Germany, 2003; Volume 209, ISBN 3540665730.

17. Roeder, E. Medicinal plants in China containing pyrrolizidine alkaloids. Pharmazie 2000, 55, 711-726. [PubMed] 
18. Ober, D.; Kaltenegger, E. Pyrrolizidine alkaloid biosynthesis, evolution of a pathway in plant secondary metabolism. Phytochemistry 2009, 70, 1687-1695. [CrossRef] [PubMed]

19. Böttcher, F.; Ober, D.; Hartmann, T. Biosynthesis of pyrrolizidine alkaloids: Putrescine and spermidine are essential substrates of enzymatic homospermidine formation. Can. J. Chem. 1994, 72, 80-85. [CrossRef]

20. Roeder, E. Medicinal plants in Europe containing pyrrolizidine alkaloids. Pharmazie 1995, 50, 83-98. [PubMed]

21. Ehmke, A.; Borstel, K.; Hartmann, T. Alkaloid N-oxides as transport and vacuolar storage compounds of pyrrolizidine alkaloids in Senecio vulgaris L. Planta 1988, 176, 83-90. [CrossRef] [PubMed]

22. Robertson, J.; Stevens, K. Pyrrolizidine alkaloids. Nat. Prod. Rep. 2014, 31, 1721-1788. [CrossRef] [PubMed]

23. Robertson, J.; Stevens, K. Pyrrolizidine alkaloids: Occurrence, biology, and chemical synthesis. Nat. Prod. Rep. 2017, 34, 62-89. [CrossRef] [PubMed]

24. Stirling, I.R.; Freer, I.K.; Robins, D.J. Pyrrolizidine alkaloid biosynthesis. Incorporation of 2-aminobutanoic acid labelled with $13 \mathrm{c}$ or $2 \mathrm{~h}$ into the senecic acid portion of rosmarinine and senecionine. J. Chem. Soc. Perkin Trans. 1997, 1, 677-680. [CrossRef]

25. Luckert, C.; Hessel, S.; Lenze, D.; Lampen, A. Disturbance of gene expression in primary human hepatocytes by hepatotoxic pyrrolizidine alkaloids: A whole genome transcriptome analysis. Toxicol. In Vitro 2015, 29, 1669-1682. [CrossRef] [PubMed]

26. Schoental, R. Liver lesions in young rats suckled by mothers treated with the pyrrolizidine (senecio) alkaloids, lasiocarpine and retrorsine. J. Pathol. 1959, 77, 485-495. [CrossRef]

27. Dickinson, J.; Cooke, M.; King, R.; Mohamed, P. Milk transfer of pyrrolizidine alkoloids in cattle. J. Am. Vet. Med. Assoc. 1976, 169, 1192-1196. [PubMed]

28. Field, R.A.; Stegelmeier, B.L.; Colegate, S.M.; Brown, A.W.; Green, B.T. An in vitro comparison of the cytotoxic potential of selected dehydropyrrolizidine alkaloids and some $N$-oxides. Toxicon 2015, 97, 36-45. [CrossRef] [PubMed]

29. Prakash, A.S.; Pereira, T.N.; Reilly, P.E.; Seawright, A.A. Pyrrolizidine alkaloids in human diet. Mutat. Res./Genet. Toxicol. Environ. Mutagen. 1999, 443, 53-67. [CrossRef]

30. Fu, P.P.; Xia, Q.; Lin, G.; Chou, M.W. Pyrrolizidine alkaloids-Genotoxicity, metabolism enzymes, metabolic activation, and mechanisms. Drug Metab. Rev. 2004, 36, 1-55. [CrossRef] [PubMed]

31. White, I.; Mattocks, A.; Butler, W. The conversion of the pyrrolizidine alkaloid retrorsine to pyrrolic derivatives in vivo and in vitro and its acute toxicity to various animal species. Chem.-Biol. Interact. 1973, 6, 207-218. [CrossRef]

32. Yang, M.; Ruan, J.; Fu, P.P.; Lin, G. Cytotoxicity of pyrrolizidine alkaloid in human hepatic parenchymal and sinusoidal endothelial cells: Firm evidence for the reactive metabolites mediated pyrrolizidine alkaloid-induced hepatotoxicity. Chem.-Biol. Interact. 2016, 243, 119-126. [CrossRef] [PubMed]

33. Macel, M. Attract and deter: A dual role for pyrrolizidine alkaloids in plant-insect interactions. Phytochem. Rev. 2011, 10, 75-82. [CrossRef] [PubMed]

34. Neto, T.d.S.N.; Gardner, D.; Hallwass, F.; Leite, A.J.M.; de Almeida, C.G.; Silva, L.N.; de Araújo Roque, A.; de Bitencourt, F.G.; Barbosa, E.G.; Tasca, T. Activity of pyrrolizidine alkaloids against biofilm formation and Trichomonas vaginalis. Biomed. Pharmacother. 2016, 83, 323-329. [CrossRef] [PubMed]

35. Hol, W.; Van Veen, J. Pyrrolizidine alkaloids from Senecio jacobaea affect fungal growth. J. Chem. Ecol. 2002, 28, 1763-1772. [CrossRef] [PubMed]

36. Pomin, V.H. Sulfated glycans in inflammation. Eur. J. Med. Chem. 2015, 92, 353-369. [CrossRef] [PubMed]

37. Chiou, W.F.; Chen, C.F.; Lin, J.J. Mechanisms of suppression of inducible nitric oxide synthase (inos) expression in raw 264.7 cells by andrographolide. Br. J. Pharmacol. 2000, 129, 1553-1560. [CrossRef] [PubMed]

38. Huang, S.; Zhou, X.L.; Wang, C.J.; Wang, Y.S.; Xiao, F.; Shan, L.H.; Guo, Z.Y.; Weng, J. Pyrrolizidine alkaloids from liparis nervosa with inhibitory activities against LPS-induced no production in raw264.7 macrophages. Phytochemistry 2013, 93, 154-161. [CrossRef] [PubMed]

39. Aboelmagd, M.; Elokely, K.; Zaki, M.A.; Said, A.; Haggag, E.G.; Ross, S.A. Anti-inflammatory of pyrrolizidine alkaloids from Heliotropium digynum. Med. Chem. Res. 2018, 27, 1066-1073. [CrossRef]

40. Ghosh, M.; Singh, H. Inhibitory effect of a pyrrolidine alkaloid, crotalaburnine, on rat paw oedema and cotton pellet granuloma. Br. J. Pharmacol. 1974, 51, 503-508. [CrossRef] [PubMed] 
41. Miser, J.S.; Smithson, W.A.; Krivit, W.; Hughes, C.H.; Davis, D.; Krailo, M.D.; Hammond, G.D. Phase II trial of indicine $\mathrm{N}$-oxide in relapsed acute leukemia of childhood: A report from the childrens cancer study group. Am. J. Clin. Oncol. 1992, 15, 135-140. [CrossRef] [PubMed]

42. Letendre, L.; Ludwig, J.; Perrault, J.; Smithson, W.A.; Kovach, J.S. Hepatocellular toxicity during the treatment of refractory acute leukemia with indicine $N$-oxide. Cancer 1984, 54, 1256-1259. [CrossRef]

43. Appadurai, P.; Rathinasamy, K. Indicine $N$-oxide binds to tubulin at a distinct site and inhibits the assembly of microtubules: A mechanism for its cytotoxic activity. Toxicol. Lett. 2014, 225, 66-77. [CrossRef] [PubMed]

44. Vlietinck, A.; De Bruyne, T.; Vanden Berghe, D. Plant substances as antiviral agents. Curr. Org. Chem. 1997, 1, 307-344. [CrossRef]

45. Pal, R.; Hoke, G.M.; Sarngadharan, M. Role of oligosaccharides in the processing and maturation of envelope glycoproteins of human immunodeficiency virus type 1. Proc. Natl. Acad. Sci. USA 1989, 86, 3384-3388. [CrossRef] [PubMed]

46. Taylor, D.; Nash, R.; Fellows, L.; Kang, M.; Tyms, A. Naturally occurring pyrrolizidines: Inhibition of $\alpha$-glucosidase 1 and anti-HIV activity of one stereoisomer. Antivir. Chem. Chemother. 1992, 3, $273-277$. [CrossRef]

47. Khan, H.; Amin, S.; Kamal, M.A.; Patel, S. Flavonoids as acetylcholinesterase inhibitors: Current therapeutic standing and future prospects. Biomed. Pharmacother. 2018, 101, 860-870. [CrossRef] [PubMed]

48. Nair, V.P.; Hunter, J.M. Anticholinesterases and anticholinergic drugs. Contin. Educ. Anaesth. Crit. Care Pain 2004, 4, 164-168. [CrossRef]

49. Benamar, H.; Tomassini, L.; Venditti, A.; Marouf, A.; Bennaceur, M.; Nicoletti, M. Pyrrolizidine alkaloids from Solenanthus lanatus DC. With acetylcholinesterase inhibitory activity. Nat. Prod. Res. 2016, 30, 2567-2574. [CrossRef] [PubMed]

50. Benamar, H.; Tomassini, L.; Venditti, A.; Marouf, A.; Bennaceur, M.; Serafini, M.; Nicoletti, M. Acetylcholinesterase inhibitory activity of pyrrolizidine alkaloids from Echium confusum coincy. Nat. Prod. Res. 2017, 31, 1277-1285. [CrossRef] [PubMed]

51. Toma, W.; Trigo, J.R.; de Paula, A.C.B.; Brito, A.R.M.S. Preventive activity of pyrrolizidine alkaloids from Senecio brasiliensis (asteraceae) on gastric and duodenal induced ulcer on mice and rats. J. Ethnopharmacol. 2004, 95, 345-351. [CrossRef] [PubMed]

52. Cheeke, P. Toxicity and metabolism of pyrrolizidine alkaloids. J. Anim. Sci. 1988, 66, 2343-2350. [CrossRef] [PubMed]

53. Mattocks, A. Toxicity of pyrrolizidine alkaloids. Nature 1968, 217, 723-728. [CrossRef] [PubMed]

54. Lin, G.; Wang, J.Y.; Li, N.; Li, M.; Gao, H.; Ji, Y.; Zhang, F.; Wang, H.; Zhou, Y.; Ye, Y. Hepatic sinusoidal obstruction syndrome associated with consumption of Gynura segetum. J. Hepatol. 2011, 54, 666-673. [CrossRef] [PubMed]

55. Ruan, J.; Gao, H.; Li, N.; Xue, J.; Chen, J.; Ke, C.; Ye, Y.; Fu, P.P.-C.; Zheng, J.; Wang, J.; et al. Blood pyrrole-protein adducts-A biomarker of pyrrolizidine alkaloid-induced liver injury in humans. J. Environ. Sci. Health Part C 2015, 33, 404-421. [CrossRef] [PubMed]

56. Zhu, L.; Xue, J.; Xia, Q.; Fu, P.P.; Lin, G. The long persistence of pyrrolizidine alkaloid-derived DNA adducts in vivo: Kinetic study following single and multiple exposures in male ICR mice. Arch. Toxicol. 2017, 91, 949-965. [CrossRef] [PubMed]

57. He, X.; Xia, Q.; Woodling, K.; Lin, G.; Fu, P.P. Pyrrolizidine alkaloid-derived DNA adducts are common toxicological biomarkers of pyrrolizidine alkaloid N-oxides. J. Food Drug Anal. 2017, 25, 984-991. [CrossRef] [PubMed]

58. Helmy, A. Review article: Updates in the pathogenesis and therapy of hepatic sinusoidal obstruction syndrome. Aliment. Pharmacol. Ther. 2006, 23, 11-25. [CrossRef] [PubMed]

59. Aydın, A.A.; Zerbes, V.; Parlar, H.; Letzel, T. The medical plant butterbur (petasites): Analytical and physiological (re) view. J. Pharm. Biomed. Anal. 2013, 75, 220-229. [CrossRef] [PubMed]

60. Chen, Z.; Huo, J.-R. Hepatic veno-occlusive disease associated with toxicity of pyrrolizidine alkaloids in herbal preparations. Neth. J. Med. 2010, 68, 252-260. [PubMed]

61. Bosi, C.F.; Rosa, D.W.; Grougnet, R.; Lemonakis, N.; Halabalaki, M.; Skaltsounis, A.L.; Biavatti, M.W. Pyrrolizidine alkaloids in medicinal tea of Ageratum conyzoides. Revista Brasileira de Farmacognosia 2013, 23, 425-432. [CrossRef] 
62. Schoental, R.; Head, M.A.; Peacock, P. Senecio alkaloids: Primary liver tumours in rats as a result of treatment with (1) a mixture of alkaloids from S. jacobaea Lin.; (2) retrorsine; (3) isatidine. Br. J. Cancer 1954, 8, 458-465. [CrossRef] [PubMed]

63. Yang, Y.-C.; Yan, J.; Doerge, D.R.; Chan, P.-C.; Fu, P.P.; Chou, M.W. Metabolic activation of the tumorigenic pyrrolizidine alkaloid, riddelliine, leading to DNA adduct formation in vivo. Chem. Res. Toxicol. 2001, 14, 101-109. [CrossRef] [PubMed]

64. Chou, M.W.; Yan, J.; Nichols, J.; Xia, Q.; Beland, F.A.; Chan, P.-C.; Fu, P.P. Correlation of DNA adduct formation and riddelliine-induced liver tumorigenesis in F344 rats and B6C3F 1 mice. Cancer Lett. 2003, 193, 119-125. [CrossRef]

65. Coulombe, R.A.; Drew, G.L.; Stermitz, F.R. Pyrrolizidine alkaloids crosslink DNA with actin. Toxicol. Appl. Pharmacol. 1999, 154, 198-202. [CrossRef] [PubMed]

66. Zhao, Y.; Xia, Q.; Yin, J.J.; Lin, G.; Fu, P.P. Photoirradiation of dehydropyrrolizidine alkaloids—Formation of reactive oxygen species and induction of lipid peroxidation. Toxicol. Lett. 2011, 205, 302-309. [CrossRef] [PubMed]

67. Xia, Q.; Chou, M.W.; Kadlubar, F.F.; Chan, P.-C.; Fu, P.P. Human liver microsomal metabolism and DNA adduct formation of the tumorigenic pyrrolizidine alkaloid, riddelliine. Chem. Res. Toxicol. 2003, 16, 66-73. [CrossRef] [PubMed]

68. GPO. Federal Register: National Toxicology Program. Available online: https://www.gpo.gov/fdsys / search/pagedetails.action?granuleId=E8-9379\&packageId=FR-2008-04-30\&acCode=FR\&collectionCode= FR (accessed on 18 April 2018).

69. Edgar, J.A.; Molyneux, R.J.; Colegate, S.M. Pyrrolizidine alkaloids: Potential role in the etiology of cancers, pulmonary hypertension, congenital anomalies, and liver disease. Chem. Res. Toxicol. 2014, 28, 4-20. [CrossRef] [PubMed]

70. Huxtable, R.J. Human Health Implications of Pyrrolizidine Alkaloids and Herbs Containing Them; CRC Press: Boca Raton, FL, USA, 1989; Volume 1, pp. 41-86. ISBN 9780849369919.

71. Culvenor, C.; Edgar, J.; Jago, M.; Outteridge, A.; Peterson, J.; Smith, L. Hepato-and pneumotoxicity of pyrrolizidine alkaloids and derivatives in relation to molecular structure. Chem.-Biol. Interact. 1976, 12, 299-324. [CrossRef]

72. Huxtable, R.; Yan, C.; Wild, S.; Maxwell, S.; Cooper, R. Physicochemical and metabolic basis for the differing neurotoxicity of the pyrrolizidine alkaloids, trichodesmine and monocrotaline. Neurochem. Res. 1996, 21, 141-146. [CrossRef] [PubMed]

73. Roulet, M.; Laurini, R.; Rivier, L.; Calame, A. Hepatic veno-occlusive disease in newborn infant of a woman drinking herbal tea. J. Pediatr. 1988, 112, 433-436. [CrossRef]

74. Small, A.; Kelly, W.; Seawright, A.; Mattocks, A.; Jukes, R. Pyrrolizidine alkaloidosis in a two month old foal. Transbound. Emerg. Dis. 1993, 40, 213-218. [CrossRef]

75. Galluzzi, L.; Vitale, I.; Aaronson, S.A.; Abrams, J.M.; Adam, D.; Agostinis, P.; Alnemri, E.S.; Altucci, L.; Amelio, I.; Andrews, D.W. Molecular mechanisms of cell death: Recommendations of the nomenclature committee on cell death 2018. Cell Death Differ. 2018, 25, 486-541. [CrossRef] [PubMed]

76. Ji, L.-L.; Zhang, M.; Sheng, Y.-C.; Wang, Z.-T. Pyrrolizidine alkaloid clivorine induces apoptosis in human normal liver 1-02 cells and reduces the expression of p53 protein. Toxicol. In Vitro 2005, 19, 41-46. [CrossRef] [PubMed]

77. Dalefield, R.R.; Gosse, M.A.; Mueller, U. A 28-day oral toxicity study of echimidine and lasiocarpine in wistar rats. Regul. Toxicol. Pharmacol. 2016, 81, 146-154. [CrossRef] [PubMed]

78. Yee, S.B.; Kinser, S.; Hill, D.A.; Barton, C.C.; Hotchkiss, J.A.; Harkema, J.R.; Ganey, P.E.; Roth, R.A. Synergistic hepatotoxicity from coexposure to bacterial endotoxin and the pyrrolizidine alkaloid monocrotaline. Toxicol. Appl. Pharmacol. 2000, 166, 173-185. [CrossRef] [PubMed]

79. Aston, N.S.; Morris, P.A.; Tanner, M.; Variend, S. An animal model for copper-associated cirrhosis in infancy. J. Pathol. 1998, 186, 215-221. [CrossRef]

80. Morris, P.; O'Neill, D.; Tanner, S. Synergistic liver toxicity of copper and retrorsine in the rat. J. Hepatol. 1994, 21, 735-742. [CrossRef]

81. Food and Drug Administration. FDA Advises Dietary Supplement Manufacturers to Remove Comfrey Products from the Market; FDA Office of Nutritional Products, Labeling, and Dietary Supplements; Center for Food Safety and Applied Nutrition: College Park, MD, USA, 2001. 
82. German Federal Department of Health Bureau. Bundesanzeiger. Dtsch. Apoth. Ztg. 1992, 132, 1406-1408.

83. International Program on Chemical Safety (IPCS). Pyrrolizidine Alkaloids Health and Safety Guide; WHO: Geneva, Switzerland, 1989; Volume 26.

84. European Food Safety Authority (EFSA). Opinion of the scientific panel on contaminants in the food chain on a request from the European Comission related to pyrrolizidine alkaloids as undesirable substances in animal feed. EFSA J. 2007, 447, 1-51.

85. European Food Safety Authority (EFSA). Scientific Opinion on Pyrrolizidine Alkaloids in Food and Feed. 2011, 9 , $1-134$.

86. European Medicines Agency. Public Statement on Contamination of Herbal Medicinal Products/Traditional Herbal Medicinal Products1 with Pyrrolizidine Alkaloids_-Transitional Recommendations for Risk Management and Quality Control; European Medicines Agency: London, UK, 2016.

87. Staatsblad van het Koninkrij der Nederlander. Besluit van 19 Januari, Houdende Vaststelling van het Warenwetbesluit Kruidenpreparaten; Ministerie van Justitie: The Hague, The Netherlands, 2001; Volume 56, Available online: https:/ / zoek.officielebekendmakingen.nl/stb-2001-56 (accessed on 10 April 2018).

88. Knight, A.P.; Walter, R.G. A Guide to Plant Poisoning of Animals in North America; Teton NewMedia: Jackson, WY, USA, 2001; ISBN 1893441113.

89. Nair, A.B.; Jacob, S. A simple practice guide for dose conversion between animals and human. J. Basic Clin. Pharm. 2016, 7, 27-31. [CrossRef] [PubMed]

90. Olson, H.; Betton, G.; Robinson, D.; Thomas, K.; Monro, A.; Kolaja, G.; Lilly, P.; Sanders, J.; Sipes, G.; Bracken, W. Concordance of the toxicity of pharmaceuticals in humans and in animals. Regul. Toxicol. Pharmacol. 2000, 32, 56-67. [CrossRef] [PubMed]

91. Habs, M.; Binder, K.; Krauss, S.; Müller, K.; Ernst, B.; Valentini, L.; Koller, M. A balanced risk-Benefit analysis to determine human risks associated with pyrrolizidine alkaloids (PA)-The case of tea and herbal infusions. Nutrients 2017, 9, 717. [CrossRef] [PubMed]

92. Pharmeuropa. Updated Work Programme of the European Pharmacopoeia; Council of Europe: Strasbourg, France, 2017.

93. Kempf, M.; Wittig, M.; Schönfeld, K.; Cramer, L.; Schreier, P.; Beuerle, T. Pyrrolizidine alkaloids in food: Downstream contamination in the food chain caused by honey and pollen. Food Addit. Contam. Part A 2011, 28, 325-331. [CrossRef] [PubMed]

94. Yu, L.; Xu, Y.; Feng, H.; Li, S.F.Y. Separation and determination of toxic pyrrolizidine alkaloids in traditional Chinese herbal medicines by micellar electrokinetic chromatography with organic modifier. Electrophoresis 2005, 26, 3397-3404. [CrossRef] [PubMed]

95. Avula, B.; Sagi, S.; Wang, Y.H.; Zweigenbaum, J.; Wang, M.; Khan, I.A. Characterization and screening of pyrrolizidine alkaloids and $\mathrm{N}$-oxides from botanicals and dietary supplements using UHPLC-high resolution mass spectrometry. Food Chem. 2015, 178, 136-148. [CrossRef] [PubMed]

96. Adamczak, A.; Opala, B.; Gryszczynska, A.; Buchwald, W. Content of pyrrolizidine alkaloids in the leaves of coltsfoot (Tussilago farfara L.) in poland. Acta Soc. Bot. Pol. 2013, 82. [CrossRef]

97. Kakar, F.; Akbarian, Z.; Leslie, T.; Mustafa, M.L.; Watson, J.; van Egmond, H.P.; Omar, M.F.; Mofleh, J. An outbreak of hepatic veno-occlusive disease in western afghanistan associated with exposure to wheat flour contaminated with pyrrolizidine alkaloids. J. Toxicol. 2010, 2010. [CrossRef] [PubMed]

98. Becerra-Jiminez, J.; Kuschak, M.; Roeder, E.; Wiedenfeld, H. Toxic pyrrolizidinalkaloids as undesired contaminants in food and feed: Degradation of the PAS from Senecio jacobaea in silage. Die Pharm.-Int. J. Pharm. Sci. 2013, 68, 636-639. [CrossRef]

99. Stillman, A.; Huxtable, R.; Consroe, P.; Kohnen, P.; Smith, S. Hepatic veno-occlusive disease due to pyrrolizidine (senecio) poisoning in Arizona. Gastroenterology 1977, 73, 349-352. [PubMed]

100. Wiedenfeld, H.; Edgar, J. Toxicity of pyrrolizidine alkaloids to humans and ruminants. Phytochem. Rev. 2011, 10, 137-151. [CrossRef]

101. Gilruth, J. Hepatic cirrhosis Affecting Horses and Cattle (So-Called "Winton Disease"); 11th Annual Report; New Zealand Department of Agriculture: Wellington, New Zealand, 1903; pp. 228-279.

102. Gilruth, J. Hepatic Cirrhosis Due to Ragwort (Senecio Jacoboea); John Mackay: Wellington, New Zealand, 1904.

103. Bull, L.; Dick, A. The chronic pathological effects on the liver of the rat of the pyrrolizidine alkaloids heliotrine, lasiocarpine, and their n-oxides. J. Pathol. 1959, 78, 483-502. [CrossRef] 
104. Mohabbat, O.; Younos, M.S.; Merzad, A.; Srivastava, R.; Sediq, G.G.; Aram, G. An outbreak of hepatic veno-occlusive disease in North-Western Afghanistan. Lancet 1976, 308, 269-271. [CrossRef]

105. Chauvin, P.; Dillon, J.-C.; Moren, A. Épidémie d'intoxication alimentaire á l'héliotrope, tadjikistan, Novembre 1992-Mars 1993. Cahiers d'Études et de Recherches Francophones/Santé 1994, 4, 263-268.

106. Merz, K.-H.; Schrenk, D. Interim relative potency factors for the toxicological risk assessment of pyrrolizidine alkaloids in food and herbal medicines. Toxicol. Lett. 2016, 263, 44-57. [CrossRef] [PubMed]

107. Bodi, D.; Ronczka, S.; Gottschalk, C.; Behr, N.; Skibba, A.; Wagner, M.; Lahrssen-Wiederholt, M.; Preiss-Weigert, A.; These, A. Determination of pyrrolizidine alkaloids in tea, herbal drugs and honey. Food Addit. Contam. Part A 2014, 31, 1886-1895. [CrossRef] [PubMed]

108. Colegate, S.M.; Gardner, D.R.; Betz, J.M.; Fischer, O.W.; Liede-Schumann, S.; Boppré, M. Pro-toxic 1,2-dehydropyrrolizidine alkaloid esters, including unprecedented 10-membered macrocyclic diesters, in the medicinally-used Alafia cf. caudata and Amphineurion marginatum (Apocynaceae: Apocynoideae: Nerieae and apocyneae). Phytochem. Anal. 2016, 257-276. [CrossRef]

109. Asres, K.; Sporer, F.; Wink, M. Occurrence of pyrrolizidine alkaloids in three ethiopian solanecio species. Biochem. Syst. Ecol. 2008, 36, 399-407. [CrossRef]

110. Aydın, A.A.; Letzel, T. Simultaneous investigation of sesquiterpenes, pyrrolizidine alkaloids and $N$-oxides in butterbur (Petasites hybridus) with an offline 2D-combination of HPLC-UV and LC-MMI-TOF-MS. J. Pharm. Biomed. Anal. 2013, 85, 74-82. [CrossRef] [PubMed]

111. Chizzola, R. Pyrrolizidine alkaloids in Adenostyles alliariae and A. glabra from the Austrian ALPS. Nat. Prod. Commun. 2015, 10, 1179-1180. [PubMed]

112. Griffin, C.T.; Gosetto, F.; Danaher, M.; Sabatini, S.; Furey, A. Investigation of targeted pyrrolizidine alkaloids in traditional chinese medicines and selected herbal teas sourced in Ireland using LC-ESI-MS/MS. Food Addit. Contam. Part A 2014, 31, 940-961. [CrossRef] [PubMed]

113. Hsieh, C.H.; Chen, H.W.; Lee, C.C.; He, B.J.; Yang, Y.C. Hepatotoxic pyrrolizidine alkaloids in Emilia sonchifolia from Taiwan. J. Food Compos. Anal. 2015, 42, 1-7. [CrossRef]

114. Stegelmeier, B.L.; Brown, A.W.; Welch, K.D. Safety concerns of herbal products and traditional Chinese herbal medicines: Dehydropyrrolizidine alkaloids and aristolochic acid. J. Appl. Toxicol. 2015, 35, 1433-1437. [CrossRef] [PubMed]

115. Lebada, R.; Schreier, A.; Scherz, S.; Resch, C.; Krenn, L.; Kopp, B. Quantitative analysis of the pyrrolizidine alkaloids senkirkine and senecionine in Tussilago farfara L. By capillary electrophoresis. Phytochem. Anal. 2000, 11, 366-369. [CrossRef]

116. Letsyo, E.; Jerz, G.; Winterhalter, P.; Beuerle, T. Toxic pyrrolizidine alkaloids in herbal medicines commonly used in Ghana. J. Ethnopharmacol. 2017, 202, 154-161. [CrossRef] [PubMed]

117. Vrieling, K.; Derridj, S. Pyrrolizidine alkaloids in and on the leaf surface of Senecio jacobaea L. Phytochemistry 2003, 64, 1223-1228. [CrossRef] [PubMed]

118. Wiedenfeld, H.; Montes, C.; Tawil, B.; Contin, A.; Wynsma, R. Pyrrolizidine alkaloid level in senecio bicolor (Wilid.) Tod, ssp. Cineraria (DC.) from middle Europe. Die Pharm. 2006, 61, 559-561.

119. Ahmad, L.; He, Y.; Hao, J.-C.; Semotiuk, A.; Liu, Q.-R.; Mazari, P. Toxic pyrrolizidine alkaloids provide a warning sign to overuse of the ethnomedicine Arnebia benthamii. J. Ethnopharmacol. 2018, 210, 88-94. [CrossRef] [PubMed]

120. Bourauel, T.; Kersten, R.; Röder, E. Pyrrolizidine alkaloids from Heliotropium arborescens. Sci. Pharm. 1995, 38, 1085-1087.

121. $\mathrm{CH}, \mathrm{C}$. Alkaloids of anchusa ofiicinalis L. Identification of the pyrrolizidine alkaloid lycopsamine. Acta Chem. Scand. B 1980, 34, 75-77.

122. El-Shazly, A.; Sarg, T.; Ateya, A.; Aziz, E.A.; Witte, L.; Wink, M. Pyrrolizidine alkaloids of Cynoglossum officinale and Cynoglossum amabile (Family boraginaceae). Biochem. Syst. Ecol. 1996, 24, 415-421. [CrossRef]

123. Roeder, E. Analysis of pyrrolizidine alkaloids. Curr. Org. Chem 1999, 3, 557-576.

124. Mulder, P.P.; Sánchez, P.L.; These, A.; Preiss-Weigert, A.; Castellari, M. Occurrence of pyrrolizidine alkaloids in food. EFSA Support. Publ. 2015, 12. [CrossRef]

125. Schulz, M.; Meins, J.; Diemert, S.; Zagermann-Muncke, P.; Goebel, R.; Schrenk, D.; Schubert-Zsilavecz, M.; Abdel-Tawab, M. Detection of pyrrolizidine alkaloids in german licensed herbal medicinal teas. Phytomedicine 2015, 22, 648-656. [CrossRef] [PubMed] 
126. Kempf, M.; Heil, S.; Haßlauer, I.; Schmidt, L.; von der Ohe, K.; Theuring, C.; Reinhard, A.; Schreier, P.; Beuerle, T. Pyrrolizidine alkaloids in pollen and pollen products. Mol. Nutr. Food Res. 2010, 54, 292-300. [CrossRef] [PubMed]

127. Lucchetti, M.A.; Glauser, G.; Kilchenmann, V.; Dübecke, A.; Beckh, G.; Praz, C.; Kast, C. Pyrrolizidine alkaloids from Echium vulgare in honey originate primarily from floral nectar. J. Agric. Food Chem. 2016, 64, 5267-5273. [CrossRef] [PubMed]

128. Edgar, J.A.; Roeder, E.; Molyneux, R.J. Honey from plants containing pyrrolizidine alkaloids: A potential threat to health. J. Agric. Food Chem. 2002, 50, 2719-2730. [CrossRef] [PubMed]

129. Kempf, M.; Beuerle, T.; Bühringer, M.; Denner, M.; Trost, D.; von der Ohe, K.; Bhavanam, V.B.; Schreier, P. Pyrrolizidine alkaloids in honey: Risk analysis by gas chromatography-mass spectrometry. Mol. Nutr. Food Res. 2008, 52, 1193-1200. [CrossRef] [PubMed]

130. Boppré, M.; Colegate, S.M.; Edgar, J.A. Pyrrolizidine alkaloids of Echium vulgare honey found in pure pollen. J. Agric. Food Chem. 2005, 53, 594-600. [CrossRef] [PubMed]

131. Beales, K.A.; Betteridge, K.; Colegate, S.M.; Edgar, J.A. Solid-phase extraction and LC-MS analysis of pyrrolizidine alkaloids in honeys. J. Agric. Food Chem. 2004, 52, 6664-6672. [CrossRef] [PubMed]

132. Betteridge, K.; Cao, Y.; Colegate, S.M. Improved method for extraction and LC-MS analysis of pyrrolizidine alkaloids and their N-oxides in honey: Application to Echium vulgare honeys. J. Agric. Food Chem. 2005, 53, 1894-1902. [CrossRef] [PubMed]

133. Culvenor, C.C.; Edgar, J.A.; Smith, L.W. Pyrrolizidine alkaloids in honey from Echium plantagineum L. J. Agric. Food Chem. 1981, 29, 958-960. [CrossRef] [PubMed]

134. Kempf, M.; Wittig, M.; Reinhard, A.; von der Ohe, K.; Blacquière, T.; Raezke, K.-P.; Michel, R.; Schreier, P.; Beuerle, T. Pyrrolizidine alkaloids in honey: Comparison of analytical methods. Food Addit. Contam. Part A 2011, 28, 332-347. [CrossRef] [PubMed]

135. Orantes-Bermejo, F.; Serra Bonvehí, J.; Gómez-Pajuelo, A.; Megías, M.; Torres, C. Pyrrolizidine alkaloids: Their occurrence in Spanish honey collected from purple viper's bugloss (echium spp.). Food Addit. Contam. Part A 2013, 30, 1799-1806. [CrossRef] [PubMed]

136. Yaber Grass, M.A.; Leicach, S.R. Changes in senecio grisebachii pyrrolizidine alkaloids abundances and profiles as response to soil quality. J. Plant Interact. 2012, 7, 175-182. [CrossRef]

137. GuimarÃEs, P.R.; Raimundo, R.L.; Bottcher, C.; Silva, R.R.; Trigo, J.R. Extrafloral nectaries as a deterrent mechanism against seed predators in the chemically protected weed Crotalaria pallida (leguminosae). Aust. Ecol. 2006, 31, 776-782. [CrossRef]

138. Barth, O.M.; Da Luz, C.F.P. Melissopalynological data obtained from a mangrove area near to rio de janeiro, brazil. J. Apicult. Res. 1998, 37, 155-163. [CrossRef]

139. Nedelcheva, A.; Kostova, N.; Sidjimov, A. Pyrrolizidine alkaloids in Tussilago farfara from Bulgaria. Biotechnol. Biotechnol. Equip. 2015, 29, S1-S7. [CrossRef]

140. Zhu, L.; Wang, Z.; Wong, L.; He, Y.; Zhao, Z.; Ye, Y.; Fu, P.P.; Lin, G. Contamination of hepatotoxic pyrrolizidine alkaloids in retail honey in china. Food Control 2018, 85, 484-494. [CrossRef]

141. Letsyo, E.; Jerz, G.; Winterhalter, P.; Dübecke, A.; von der Ohe, W.; von der Ohe, K.; Beuerle, T. Pyrrolizidine alkaloids in floral honeys of tropical Ghana: A health risk assessment. Food Addit. Contam. Part B 2017, 10, 300-310. [CrossRef] [PubMed]

142. Jhansi, P.; Kalpana, T.; Ramanujam, C. Pollen analysis of some Apis cerana Fabr honeys from Andhra Pradesh, India. Apidologie 1994, 25, 289-296. [CrossRef]

143. Eller, A.; Chizzola, R. Seasonal variability in pyrrolizidine alkaloids in senecio inaequidens from the Val Venosta (Northern Italy). Plant Biosyst.-Int. J. Deal. All Aspects Plant Biol. 2016, 150, 1306-1312. [CrossRef]

144. Lorena, L.; Roberta, M.; Alessandra, R.; Clara, M.; Francesca, C. Evaluation of some pyrrolizidine alkaloids in honey samples from the Veneto region (Italy) by LC-MS/MS. Food Anal. Methods 2016, 9, 1825-1836. [CrossRef]

145. Martinello, M.; Borin, A.; Stella, R.; Bovo, D.; Biancotto, G.; Gallina, A.; Mutinelli, F. Development and validation of a quechers method coupled to liquid chromatography and high resolution mass spectrometry to determine pyrrolizidine and tropane alkaloids in honey. Food Chem. 2017, 234, 295-302. [CrossRef] [PubMed]

146. Kast, C.; Dübecke, A.; Kilchenmann, V.; Bieri, K.; Böhlen, M.; Zoller, O.; Beckh, G.; Lüllmann, C. Analysis of swiss honeys for pyrrolizidine alkaloids. J. Apicult. Res. 2014, 53, 75-83. [CrossRef] 
147. Thapa, R.; Wongsiri, S. Eupatorium odoratum: A honey plant for beekeepers in Thailand. Bee World 1997, 78, 175-178. [CrossRef]

148. Sorkun, K.; Dogan, C. Pollen analysis of Rize-Anzer (Turkish) honey. Apiacta 1995, 3, 75-81.

149. Osborne, J.L. Borage. Bee World 1999, 80, 33-36. [CrossRef]

150. Burgett, D.M. Pyrrolizidine Alkaloids: Their Occurrence in Honey from Tansy Ragwort Senecio jacobaea L.; American Association for the Advancement of Science: Washington, DC, USA, 1977.

151. Mudge, E.M.; Jones, A.M.P.; Brown, P.N. Quantification of pyrrolizidine alkaloids in North American plants and honey by LC-MS: Single laboratory validation. Food Addit. Contam. Part A 2015, 32, 2068-2074. [CrossRef] [PubMed]

152. Daners, G.; Tellería, M.C. Native vs. Introduced bee flora: A palynological survey of honeys from Uruguay. J. Apicult. Res. 1998, 37, 221-229. [CrossRef]

(C) 2018 by the authors. Licensee MDPI, Basel, Switzerland. This article is an open access article distributed under the terms and conditions of the Creative Commons Attribution (CC BY) license (http://creativecommons.org/licenses/by/4.0/). 